\title{
Efficacy of removable rigid dressing after transtibial amputation in diabetes mellitus patients
}

\author{
Evi R.N. Hidayati, ${ }^{1}$ Elida Ilyas, ${ }^{1}$ I N. Murdana, ${ }^{1}$ Tri J.E. Tarigan, ${ }^{2}$ Retno A. Werdhani ${ }^{3}$ \\ ${ }^{1}$ Department of Physical Medicine and Rehabilitation, Faculty of Medicine, Universitas Indonesia, Jakarta, Indonesia \\ ${ }^{2}$ Department of Internal Medicine, Faculty of Medicine, Universitas Indonesia, Jakarta, Indonesia \\ ${ }^{3}$ Department of Community Medicine, Faculty of Medicine, Universitas Indonesia, Jakarta, Indonesia
}

\begin{abstract}
Abstrak
Latar belakang: Tujuan penelitian ini adalah untuk mengetahui efektivitas pemakaian Removable rigid dressing (RRD) dibandingkan dengan perban elastik pada pasien diabetes melitus pascaamputasi transtibia.

Metode: Desain penelitian adalah studi intervensi dengan menggunakan sampling konsekutif, dilakukan randomisasi untuk membagi menjadi dua kelompok perlakuan yaitu perban elastik dan RRD. Dua puluh tiga subjek yang berhasil dianalisis. Volume edema puntung dinilai dengan mengukur jumlah volume air yang tertumpah dari gelas ukur. Volume edema dan nyeri di evaluasi setiap tujuh hari selama delapan minggu. Perban elastik harus dibalut ulang setiap empat jam per hari dan RRD dicetak ulang setiap tujuh hari saat evaluasi.
\end{abstract}

Hasil: Penurunan volume edema puntung lebih cepat di kelompok RRD dibandingkan perban elastik pada minggu pertama dan kedua, secara statistik bermakna $(p=0,03, p=0,01)$ serta percepatan waktu puntung menjadi tidak edema $(p=0,03)$. Rerata penurunan volume edema puntung di kelompok RRD sebesar 63,85\% di minggu kedua, dan 34,35\% di kelompok perban elastik. Terdapat kecendrungan penurunan nilai nyeri puntung yang lebih cepat di kelompok RRD (minggu 4,83 $\pm 1,95$ ) dibandingkan kelompok perban elastik (minggu 5,18 $\pm 2,31$ ) walaupun secara statistik tidak bermakna $(p=0,6)$. Analisis kesintasan dengan uji regresi Cox terhadap waktu penurunan volume edema didapatkan nilai $R R=3,088$ (CI 95\%: 1,128-4,916).

Kesimpulan: RRD mempercepat penurunan volume edema puntung dibandingkan perban elastik dan kemungkinan tiga kali lebih cepat untuk puntung menjadi tidak edema dibandingkan perban elastik. Terdapat kecenderungan lebih cepat waktu puntung menjadi tidak nyeri di kelompok RRD dibandingkan perban elastik walaupun secara statistik tidak bermakna. (Med J Indones. 2013;22:16-21)

\begin{abstract}
Background: The aim of this study was to evaluate the RRD's efficacy in decreasing stump edema and pain compared to elastic bandage for diabetic mellitus patients after transtibial amputation.

Methods: Interventional research was using consecutive sampling. Subjects were randomized into two groups: RRD and elastic bandage. Twenty-three subjects were analyzed. Stump edema volume was measured by the amount of water spilled out from volume glass. Elastic bandage was reapplied every 4 hours and RRD was refitted every 7 days during evaluation time. Stump edema volume was evaluated every 7 days during the 8 week observation.

Results: There was a significant decrease of stump volume in RRD group during the first and second week $(p=0.03, p=$ $0.01)$ and the edema decreasing time was also significant $(p=0,03)$. The average decrease of edema volume in RRD was $63.85 \%$ of second week and in the elastic bandage group was $34.35 \%$. There were a tendency of pain reduction time in RRD group ( $4.83 \pm 1.95$ weeks) compared to elastic bandage group ( $5.18 \pm 2.31$ weeks). Cox regression result of decreasing edema volume time was 3.088 (CI 95\%: $1.128-4.916$ ).

Conclusion: This study found that there was stump edema volume acceleration in RRD group, it was three times faster for stump to become not edematous compared to elastic bandage group. There was a tendency of faster decreasing stump pain in RRD group than elastic bandage group, eventhough this result was not statistically significant. (Med J Indones. 2013;22:16-21)
\end{abstract}

Keywords: Diabetes mellitus, removable rigid dressing, transtibial amputation

Diabetes mellitus (DM) is a symptom of diseases characterized by increased blood glucose levels due to the inability of the body to produce insulin, or receptor resistance, or both. Indonesia is the fourth-ranked country in the world after India, China and America in the number of diabetics mellitus. ${ }^{1}$ According to data of Riset Kesehatan Dasar (Riskesdas, Basic Health Research) 2007 , there were $5.7 \%$ of the total population in urban areas in Indonesia, suffering DM. By 2030, WHO (World Health Organization) estimated that there will be 194 millions people suffering from diabetes mellitus in the world. ${ }^{2-4}$

The incidence of transtibial amputations in Indonesia reaches $25-30 \%$ of the overall incidence of lower limbs amputation. ${ }^{3,4}$ It is the best level for peripheral artery disease caused by diabetes mellitus, because there is still large blood vessel to vascularization. The remaining of gastrocnemius and soleus muscles will be suitable to be used as skin flap to serve as good cushion for prosthetic. ${ }^{5}$ 
Common complication are stump edema, pain (stump pain and phantom pain), knee joint contractures and impaired wound healing as a result of prolonged use of functional prosthetic. Another disadvantage is the long duration of rehabilitation period making less costeffective. ${ }^{6-8}$ The main principle of rehabilitation after transtibial amputation is to control edema and pain so that the maturation of stump can be facilitated as soon as possible. Stump is considered mature when it has obtained a conical shape form, no edema, no stump pain and soft tissue atrophy occurred around the stump..$^{6,9-11}$

There are several ways of dressings after transtibial amputation that had long been done by the clinician, they are the soft gauze, elastic bandage and Removable Rigid Dressing (RRD). Elastic bandage is a conventional method of dressing after transtibial amputation using a figure of eight technique to control edema and pain. ${ }^{7,11,12}$ Complications that often arise from the use of elastic bandage is the emergence of dogears and tourniquet effect due to errors in the installation process, resulting in ischemia at distal stump, causes necrosis and damage to the skin flap on the stump. ${ }^{9,13}$ In a study conducted by Deutch et al, ${ }^{14}$ it was found that the emergence of skin flap breakdown caused by elastic bandage after transtibial amputation resulted in the delay of stump healing process (RRD $51.2+19.4$ days compared with $64.7+29.5$ days with elastic bandage).

Another alternative in controlling edema and pain after transtibial amputation is by using RRD, which is made of Plaster of Paris. It aims to reduce the adverse effects of elastic bandage use and the use of RRD allows continuous monitoring of wound healing.

RRD study was initiated by Wu et $\mathrm{al}^{9}$ which used RRD found wound healing after transtibial amputation caused by trauma. Further studies was conducted by Mueller et al, ${ }^{13}$ Deutsch et al, ${ }^{14}$ and Janchai et al. ${ }^{15}$ This four studies compared the effects of the use of RRD with elastic bandage. These studies result showed that RRD speeds up the relieve of stump edema. Furthermore, it has not been found to have beneficial effect on diabetes mellitus. ${ }^{9,11,16}$

The purpose of this study was to examine the effectiveness of the use of RRD compared with elastic bandage in patients with diabetes mellitus after transtibial amputation. The hypothesis was that there are differences in volume reduction rate decreased stump edema and stump pain in patients with diabetes mellitus after transtibial amputation who get RRD compared with elastic bandage.

\section{METHODS}

This study was a clinical trial on patients with diabetes mellitus after transtibial amputation in three hospitals, Cipto Mangunkusumo, Persahabatan and Marzuki Mahdi General Hospitals from June 2010 until January 2012. Sampling was conducted by using consecutive sampling and randomization through a block of two to divide subjects into two groups: elastic bandage group as controlled group and the group receiving treatment RRD.

\section{Study subjects}

Inclusion criteria were diabetes mellitus patients after transtibial amputation within 1 month, visual analog scale $(\mathrm{VAS})>3$, controlled blood glucose, ankle brachial index (ABI) from 0.8 to 1.2 and has agreed to participate on the study by giving the informed consent. Exclusion criteria were patients with impaired immunity (leucocytes $<1500 / \mu \mathrm{L}$ ), other causes of amputation aside from DM, and the presence of cognitive impairment and handicap in hand, unless the patient had a care assistant who can help with the application of the elastic bandage. Subjects will be excluded from the study if there is damage to sutures skin flap in the RRD group.

From the total of 26 subjects who were suitable to the inclusion and exclusion criteria, there were 23 subjects to be divided into RRD group (12 subjects) and elastic bandage group (11 subjects), and had performed statistical analysis. Two subjects died during the study period and one person refused to participate in the study.

\section{Study procedures}

The subjects who met the inclusion and exclusion criteria were asked to sign the informed consent to be enrolled in the study. The procedure was followed by measurement of initial stum edema volume and stump pain scale. Stump edema volume was measured by the amount water spilled out from volume glass. Stump pain was evaluated by using visual analog scale (VAS) between 0 to 10 ( 0 indicates no pain and 10 indicates unbearable pain). Stump edema volume and stump pain were evaluated every 7 days during 8 weeks intervention.

Intervention given to the control group was dressing by using elastic bandage with figure of eight technique, which was reapplied every 4 hours. RRD were fitted from Plester of Paris at first week and was refitted every 7 days for a total 8 weeks intervention. During the use of RRD, patients were required to wear an 
extra layer of socks (maximum 4 layers) under the RRD to provide continuously total contact between the stump and RRD. Stumps were not considered if edema obtained was accompanied by the change

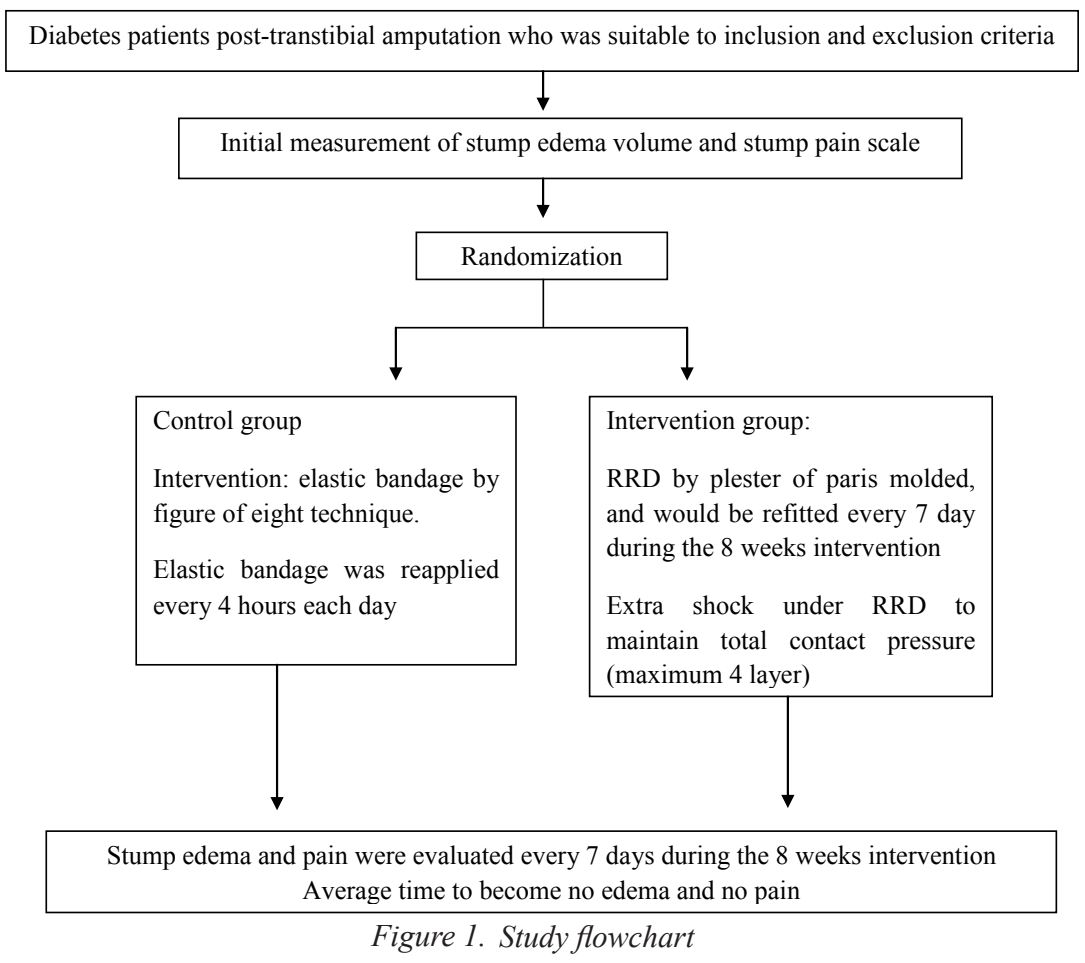

Table 1. Basic characteristics of study subjects

\begin{tabular}{|c|c|c|}
\hline & $\operatorname{RRD}(\mathrm{n}=12)$ & Elastic bandage $(\mathrm{n}=11)$ \\
\hline Age (years $\pm \mathrm{SD})$ & $54.33 \pm 8.06$ & $59.91 \pm 8.949$ \\
\hline \multicolumn{3}{|l|}{ Gender } \\
\hline Male n $(\%)$ & $5(38.5)$ & $8(61.5)$ \\
\hline Female n $(\%)$ & $7(70)$ & $3(30)$ \\
\hline Ankle brachial index (ABI) & $0.9(0.8-1)$ & $0.81(0.8-1)$ \\
\hline Years of DM & $8.42 \pm 6.904$ & $12.55 \pm 9.55$ \\
\hline \multicolumn{3}{|l|}{ Foot side } \\
\hline Right n (\%) & $5(41.7)$ & $7(58.3)$ \\
\hline Left n $(\%)$ & $7(63.6)$ & $4(36.4)$ \\
\hline Days of amputation & $10 \pm(4-21)$ & $14.45 \pm 6.29$ \\
\hline Initial edema volume $\left(\mathrm{cm}^{3}\right)$ & $277.50 \pm 105.304$ & $249.09 \pm 103.774$ \\
\hline Initial VAS scale $(0-10)$ & $4.50 \pm 1.382$ & $4.000(3.00-5.00)$ \\
\hline \multicolumn{3}{|l|}{ Flap of skin } \\
\hline Except posterior $\mathrm{n}(\%)$ & $6(66.7)$ & $3(33.3)$ \\
\hline Posterior n (\%) & $6(57.1)$ & $8(42.9)$ \\
\hline \multicolumn{3}{|l|}{ Blood glucose outcome } \\
\hline Uncontrolled n (\%) & $3(60.0)$ & $2(40.0)$ \\
\hline Controlled n (\%) & $9(50.0)$ & $9(50.0)$ \\
\hline \multicolumn{3}{|l|}{ Infection } \\
\hline Infection $\mathrm{n}(\%)$ & $8(53.3)$ & $7(46.7)$ \\
\hline No infection $\mathrm{n}(\%)$ & $4(50)$ & $4(50)$ \\
\hline
\end{tabular}


in volume of stump edema in three consecutive measuremens. Each subject will be evaluated for stump edema volume and VAS scale every 7 days for 8 weeks of observation (Figure 1).

\section{Data analysis}

Data management was done with SPSS version 17.0. Test for normality of data known to coefficient of variance $(\mathrm{CoV})$. Bivariate analysis performed to determine the comparative distribution of confounding variables in the control group and treatment, and performed multivariate analysis to assess factors - the dominant factor affecting the decline in the volume of edema and stump pain. Unpaired t test was performed to evaluate the acceleration for decreasing stump edema volume, and stump pain between two groups. Then performed survival analysis using Cox regression to assess the RR (relative risk) between the relationships of time it takes for the stump become not edema.

\section{RESULTS}

Basic characteristics of study subjects can be seen in table 1.

\section{Reduction of stump edema volume}

Table 2 and 3 showed the differences between two groups in speed of stump edema volume which happened in the first 2 weeks in RRD group with average $63.85 \%$ compared to elastic bandage group of only $34.35 \%$. There is no significant in decrease stump edema volume in week III - VIII. The stump will be free of edema at week $5.08 \pm 1.17$ in the RRD group and $6.82 \pm 1.31$ weeks in the elastic bandage group which was statistically significant $(p=0.03)$.

Clinically, reduction of stump edema volume was faster in RRD group. It's caused by reduction of

Table 2. Unpaired t-test is to assess decrease stump edema volume, week I-VIII $\left(\mathrm{cm}^{3}\right)$

\begin{tabular}{lccc}
\hline Week & RRD & Elastic bandage & $\mathrm{p}$ \\
\hline 0 - I & $84.33 \pm 54.02$ & $44.54 \pm 25.93$ & 0.03 \\
0 - II & $123.33 \pm 76.02$ & $66.36 \pm 28.46$ & 0.01 \\
0 - III & $133.33 \pm 62.24$ & $94.55 \pm 33.57$ & 0.08 \\
0 - IV & $155.06 \pm 60.83$ & $110.91 \pm 36.46$ & 0.05 \\
0 - V & $171.08 \pm 58.97$ & $130.91 \pm 45.06$ & 0.08 \\
0 - VI & $182.75 \pm 56.96$ & $141.37 \pm 55.41$ & 0.09 \\
0 - VII & $87.92 \pm 70.6$ & $100.45 \pm 76.17$ & 0.07 \\
0 - VIII & $87.92 \pm 70.6$ & $106.45 \pm 76.17$ & 0.6 \\
\hline
\end{tabular}

Table 3. The mean value for the stump becomes time not edema (weeks)

\begin{tabular}{lccc}
\hline & $\mathrm{n}$ & mean $\pm \mathrm{SD}$ & $\mathrm{p}$ \\
\hline RRD & 12 & $5.08 \pm 1.17$ & 0.03 \\
Elestic bandage & 11 & $6.82 \pm 1.31$ & \\
\hline
\end{tabular}

incidence in skin flap breakdown and acceleration of stump healing process in RRD group. Acceleration in decrease of stump edema volume will be fastening of fitting process for functional prosthetic.

Table 4. Unpaired t-test for decreasing stump pain scale

\begin{tabular}{lccc}
\hline \multicolumn{1}{c}{ Week } & RRD & Elastic bandage & $\mathrm{p}$ \\
\hline 0 - I & 0 & 0 & 1.000 \\
0 - II & $1.42 \pm 1.08$ & $1.09 \pm 1.22$ & 0.899 \\
0 - III & $2.5 \pm 1.24$ & $1.73 \pm 1.00$ & 0.318 \\
0 - IV & $3.0 \pm 1.35$ & $2.00 \pm 1.00$ & 0.401 \\
0 - V & $3.25 \pm 1.422$ & $2.00 \pm 1.56$ & 0.618 \\
0 - VI & $3.25 \pm 1.422$ & $2.64 \pm 1.03$ & 0.377 \\
0 - VII & $3.5 \pm 1.440$ & $3.01 \pm 1.22$ & 0.628 \\
0 - VIII & $3.66 \pm 1.56$ & $3.36 \pm 1.28$ & 0.752 \\
\hline
\end{tabular}

\section{Reduction of stump pain scale}

Table 4 shows a reduction of stump pain scale until the end of the study. There was no statistically significant difference $(p>0.05)$ in both study groups, but there was a tendency of decreasing in VAS scale to higher and faster in the RRD group than the elastic bandage group. RRD group will reach a condition of stump with no pain in $4.83 \pm 1.946$ weeks and in the elastic bandage group in $5.18 \pm 2.31$ weeks, although the result was not statistically significant $(\mathrm{p}=0.699)$.

\section{Cox regression test and the value of $R R$}

Multivariate analysis was performed by using backward technique in Cox regression test to evaluate the influences of each variables in the acceleration of decreasing stump edema volume and stump pain. Based on these tests, it was found that the intervention was statistically significant for RRD and elastic bandages to decrease stump edema volume. A value of RR obtained 3.088 (CI 95\%: 1.1284.916). It means that the RRD decreased stump edema volume three times faster than the elastic bandage.

\section{DISCUSSION}

One of the conditions affecting the rehabilitation of patients with diabetes mellitus after transtibial amputation is the infection which resulted in inhibition 
of wound healing process due to hyperglycemic conditions. It will cause interference with immune function and inhibits the proliferation of collagen maturation. The major goal after transtibial amputation is to accelerate inflammatory process that can reduce stump edema faster, may periodically evaluate the wound and can speed up the fitting of a functional prosthesis. ${ }^{17,18}$

Reduction in stump edema volume was three times faster in the first 2 weeks RRD. It was influenced by several factors. First, the total contact pressured by RRD and evenly distributed across the surface of the stump, thus prevent it to become loose when the stump edema volume begin to shrink or during movement. The condition is different when using elastic bandage, in which the total contact is easy to become loose by moving stump. Fairly distributed pressure can reduce the number of simultaneous extravasation fluid volume to the stump area, reducing the amount of inflammatory cell chemotaxis and substances that migrate into the stump area. As a result, reduced inflammatory process can be accelerated, resulting in a speed up of wound healing and no further stump edema formation. The second factor is due to ability of both subject and care giver in application of elastic bandage in the elastic bandage group who were still learning to apply the figure of eight technique properly. The third factor is that RRD can withstand trauma and movement has minimal impact on trauma. As a result of acceleration of wound healing process, RRD study group experienced a faster stump edema relieve by three times compared to the elastic bandage group. Clinically, acceleration in decrease stump edema volume could speed up stump maturity and thus enable postamputation patients to use a functional prosthetic to do their activitiy of daily living as soon as possible.

This result consistent with previous studies conducted by Wu et al, ${ }^{9}$ Mueller et al, ${ }^{13}$ Deuscth et $\mathrm{al}^{14}$ and Janchai et al. ${ }^{15}$ The present study found that the administration of RRD could accelerate the decline in the volume of stump edema, although the result was not statistically significant.

Insignificant result of reduction of VAS scale is due to by several consideration. First, the pain was reduced by decreasing the stump edema volume in both interventions. Second, subjects felt more comfortable and relatively less painful each time the RRD is changed or if elastic bandage when reapplied every 4 hours. The total contact of RRD and elastic bandage when reapplied every 4 hours were tight enough to reduce and accelerate decrease of stump pain. It is one method that helps to reduce stump pain by working as a gate control theory that activation of $A \alpha$ and $A \beta$ nerve fibers would inhibit the delivery of the type $\mathrm{C}$ nerve fibers that serve to deliver sensation of pain., ${ }^{9,19,20,21}$ The third factor is the presence of peripheral neuropathy experienced by the subjects before amputation. ${ }^{17,21}$ Fifty percent of patients with diabetes mellitus experienced peripheral neuropathy. This is consistent with the study done by Emelia $\mathrm{J}$ et $\mathrm{al}^{22}$ which found that peripheral neuropathy occurred in $88.2 \%$ of the subjects of diabetic foot ulcers who underwent major amputation. ${ }^{23}$

There were two additional results from this research. First, there were no significant differences in terms of the disappearance of phantom pain in both treatment groups. Phantom pain is pain experienced by patients with post-amputation from an already amputatedlimbs. The absence of phantom pain occurs because the majority of patients with diabetes mellitus who have peripheral neuropathy occurred pre-amputation. Therefore, most of the subjects did not feel the sensation of pain in the leg to be amputated, and the result is not formation of the engram in the brain about the experience of pre-amputation pain. The absence of preamputation pain sensation will relieve phantom pain phenomenon faster. ${ }^{8,16}$ The results are consistent with the study by Emelia $\mathrm{J}$ et $\mathrm{a}^{22}$ who observed that only $8.8 \%$ of research subjects who are still complaining about phantom pain after major amputation.

Second, the formation of conical shape on the stump statistically significant in the RRD group $(p=0.009)$. Subject in RRD group felt safe and comfortable using the RRD, while those in the elastic bandage group experienced a side effect of damage to the skin flap. Additional results are further strengthened by the use of research results that the RRD in patients with transtibial amputation stump can accelerate stump maturity which are marked with a conical shape form of stump, no edema and no pain, and the prevention of complications of damage to the skin flap during the time of the post-amputation rehabilitation.

Limitations of this study are small sample size and only meet $80 \%$ of the power of the study. This is due to the difficulty of finding subjects, because there has been establishment of integrated foot care management of diabetes mellitus that transtibial amputation action decreases dramatically nowadays.

In conclusion, the use of RRD was found to be statistically significant in accelerating the decline in stump edema volume and decreasing the stump edema volume up to three time faster for stump become not edema. RRD could accelerate the stump maturity, which is characterized by a conical shape, no edema and no pain, compared with the use of elastic bandages 
in patients after transtibial amputation. Moreover, the use of RRD also has an effect of accelerating the stump pain relieve compared to elastic bandage, although the result is not statistically significant.

It is necessary to do further research with a larger sample size to be able to asses the effectiveness of RRD in decreasing stump pain and duration of stump maturation to consider appropriate time of functional prosthetic to be used.

\section{REFERENCES}

1. Indonesian Society of Endocrinology. Consensus management and prevention of type 2 diabetes mellitus in Indonesia; 2011.

2. Ministry of Health Indonesia. Basic health research (RISKESDAS) 2007. Jakarta; 2007. p.156-60.

3. Waspadji S. Review of conflict of metabolic factors and immune response in patients type 2 diabetes mellitus: relation to the ulcer / gangrene diabetes [dissertation]. Mount Pleasant (MI): Universitas Indonesia; 2002.

4. Centers for Disease Control and Prevention (CDC). Long term trend in diabetes [Internet]. Oct 2011. Available from: http://www.cdc.gov/diabetes/statistics.

5. Stahel PF, Oberholzer A, Morgan SJ, et al. Concepts of transtibial amputation: Burgess technique versus modified Bruckner procedure. ANZ J Surg. 2006;76:942-6.

6. World Health Organization, United States Department of Defense Moss Rehab Amputee Rehabilitation Program. The rehabilitation of people with amputations. Moss Rehab Hospital: USA; 2004.

7. Smith DG, McFarland LV, Sangeorzan BJ, et al. Postoperative dressing and management strategies for transtibial amputations: a critical review. J Rehabil Res Dev. 2003;40(3):213-24.

8. Gitter A, Bosker G. Upper and lower extremity prosthetics. In: physical medicine \& rehabilitation: principles and practice. Chapter 61, 4th ed. Lippincott Williams \& Wilkins; 2005. p. 1326-53.

9. $\mathrm{Wu}$ Y, Krick H. Removable rigid dressing for below-knee amputees. Journal of Clinical Prosthetics and Orthotics. 1987;11(1):33-44.

10. Kuiken TA, Miller L, Lipschut R, et al. Rehabilitation of people with limb amputation lower. In: Delisa, editor.
Physical medicine and rehabilitation. 3rd ed. Elsevier Saundersm; 2007. p. 283-323.

11. Sum CF, Lim SC, Tavintharan S. Peripheral arterial disease and diabetes foot care. Singapore Med J. 2008;49(2):93-4.

12. Manella KJ. Comparing the effectiveness of elastic bandages and Shrinker shock for lower extremities amputees. Journal of Physical Therapy. 1980;6(3).

13. Mueller MJ. Comparison of removable rigid elastic bandages and dressings in pre prosthetic management of patients with below-knee amputations. Journal of Physical Therapy. 1982:62(10):1438-41.

14. Deutsch A, English RD. Removable rigid versus soft dressing dressing: a randomized controlled study with dysvascular, trans-tibial amputees. Orthot Prosthet Int. 29(2):193-200.

15. Janchai S, Boonhong J, Tiamprasit J. Comparison of removable rigid dressing and elastic bandages in reducing the volume of residual limb knee amputees below. J Med Assoc Thai. 2008;91(9):1441-6.

16. Harker J. Wound healing complications associated with lower limb amputation. World Wide Wound [Internet]. 2006 Sept. Available from: http://www.worldwidewounds. com/2006/september/Harker/Wound-HealingComplications-Limb-Amputation.html.

17. Mishra M, Kumar H. Tripatri K. Delayed diabetic wound healing and the role of silver nanoparticles. Digest Journal of Nanomaterial and Biostructure. 2008;3(2):43-54.

18. Wu Y, Keagy RD, Krick HJ, et al. An innovative removable rigid dressing technique for below the knee amputation. J Bone Joint Surg Am. 1979;61:724-9.

19. Tan JC. Practical manual of physical medicine and rehabilitation, diagnostic, theurapeutic and basic problem. Chapter 4. Mosby Publishing; 1998. p. 229-47.

20. Kusumaningsih W. Fenomena fantom pasca amputasi anggota gerak akibat trauma dan faktor-faktor yang mempengaruhinya [dissertation]. Mount Pleasant (MI): Universitas Indonesia; 2004. Indonesian.

21. Steinberg FU. Rehabilitation of the diabetic amputee. In: Levin ME, Oneil LW, editors. The diabetic foot. 3rd ed. Toronto: The CV Mosby Co.; 1983. p. 303-28.

22. Emelia J. Analysis of clinical outcomes in diabetic foot patients and type 2 diabetes mellitus factors affecting. Universitas Indonesia; 2011.

23. Setiadi TH, Widjajalaksmi, Ilyas E, et al. Effect of pumping exercise to ankle brachial index in type 2 diabetes mellitus patient with ulcer. Indonesian Journal of Physical Medicine and Rehabilitation. 2010;1:11-7. 